\title{
A PRINCIPLED APPROACH TO DEFAMATION CLAIMS IN NEW ZEALAND: UNTANGLING THE HARM THRESHOLD
}

\author{
Emma Croskery*
}

\begin{abstract}
The threshold requirement of reputational harm for bringing a defamation claim needs clarification. Although recent case law shows that a threshold exists, precedents conflict as to what exactly the threshold requires, and who bears the burden of proof. There is further judicial disagreement on whether the principle that defamation claims can be struck out if no real and substantial tort has been committed, the Jameel principle, applies in New Zealand. This article suggests that both the harm threshold (more accurately described as a "tendency to cause harm" threshold, as it does not require proof of actual harm) and the Jameel principle have a valuable place in New Zealand's defamation law and their application requires endorsement and clarification at appellate level. Further, this article highlights that the principles are conceptually distinct and their fusion is undesirable in New Zealand.
\end{abstract}

\section{INTRODUCTION}

Issues in defamation law often centre on the same essential question: how should the balance be struck between the defendant's right to freedom of expression and the claimant's right to protection of reputation? This question is at the forefront of debates regarding whether a claimant must have suffered reputational harm to have an actionable defamation claim. Prior to the passage of the Defamation Act 2013, the United Kingdom courts developed two methods of jettisoning claims brought by plaintiffs who suffered minimal harm. The first was a harm threshold, which rather than requiring proof of actual harm, required that the publication have a tendency to cause reputational harm. The threshold has received support in recent New Zealand judgments but has been interpreted inconsistently, with judges disagreeing on what level the threshold is pitched at ${ }^{1}$ and which party

* Submitted as part of the LLB (Honours) Degree, Faculty of Law, at Victoria University of Wellington, 2018. I am extremely grateful for the guidance and support I received from my supervisor, Steven Price.

1 It is unclear whether the threshold requires that the publication has a tendency to cause serious harm: see $C P A$ Australia Ltd $v$ New Zealand Institute of Chartered Accountants [2015] NZHC 1854 at [120]; substantial 
bears the burden of proof. $^{2}$ The second method allows the court to strike out prima facie actionable claims as an abuse of process where no real and substantial tort has been committed. The strike out is predicated on the harm caused being so minor that the time and expense necessitated by continued litigation would be disproportionate to any vindication the claimant could achieve. Because this jurisdiction is only engaged where harm to reputation is minimal, ${ }^{3}$ there is significant overlap between the two theories, although their conceptual grounding is distinct.

Using this "twin track" approach, a claim could fail either because:

(1) the publication does not satisfy the threshold requirement that the meaning of the words have a tendency to cause reputational harm (the Thornton principle); or

(2) of a successful strike out application on the basis that continuing the claim would be a disproportionate drain on judicial resources because no real and substantial tort has been committed (the Jameel principle).

Track one only looks at the meaning of the words published, and deals with claims which are not actionable because the meaning of the publication does not meet the required standard of seriousness to be defamatory. Conversely, track two responds to prima facie actionable claims, the pursuit of which would be a disproportionate drain on court resources due to external evidence which proves the lack of a real and substantial tort.

This article argues for endorsement of both tracks in New Zealand. Part II explains why a bar to trivial claims is necessary. New Zealand's statutory context is set out in Part III. The United Kingdom position is examined in Part IV, including a discussion of the twin track approach which operated prior to the Defamation Act 2013 (UK). Part V analyses New Zealand's case law (in particular, how it has responded to United Kingdom developments) and concludes that although support for both tracks is present in New Zealand, clarification is required before the twin track approach can function effectively in this jurisdiction. Conflicting precedents at High Court level mean that appellate consideration of the issue is required. Both tracks should be endorsed and their precise scope needs to be defined.

Against this background, Part VI recommends that the New Zealand courts should adopt the twin track approach rather than fuse the tracks, as has recently occurred in the United Kingdom. ${ }^{4}$ The

harm: see Opai v Culpan (No 2) [2016] NZHC 3004 at [32]; or if more than minor harm will suffice: see Sellman v Slater [2017] NZHC 2392, [2018] 2 NZLR 218 at [68].

2 Palmer J in Sellman v Slater, above n 1, placed the burden on the defendant. All other judges have placed the burden on the claimant.

3 Jameel v Dow Jones \& Co Inc [2005] EWCA Civ 75, [2005] QB 946 at [40].

4 Although as will be addressed in Part IV(D), following the Court of Appeal judgment in Lachaux $v$ Independent Print Ltd [2017] EWCA Civ 1334, [2018] 2 WLR 387 [Lachaux v Independent Print Ltd (CA)] this position is far from settled. 
tracks are conceptually distinct and incorporating aspects of the Jameel principle into the Thornton threshold eradicates the presumption of harm, which places an unreasonable burden on claimants. The existence of two distinct routes for disposing of unworthy claims can ensure that most trivial or disproportionate claims are able to be struck out without excessively burdening claimants and without a need for statutory intervention. This approach is workable and conceptually sound, and strikes an appropriate balance between the defendant's right to freedom of expression and the claimant's right to reputation.

\section{THE NEED FOR A BAR TO TRIVIAL CLAIMS}

The growing appetite for restricting defamation claims largely results from three factors. Firstly, defamation trials, which are notoriously drawn-out and technical, impose a hefty financial burden on the parties and the courts. ${ }^{5}$ Growing concern about the consumption of finite court resources has fostered judicial desire to dispose of trivial proceedings at an early stage. ${ }^{6}$ Expending judicial resources on trivial defamation trials wastes public money ${ }^{7}$ and slows down access to the courts, hindering the administration of justice. ${ }^{8}$ Secondly, a defamation lawsuit, even one which ultimately fails, is a direct interference with the defendant's right to freedom of expression, a right which society is increasingly protective of. ${ }^{9}$ A third (and related) factor is the perception of the tort as excessively "plaintiff friendly". ${ }^{10}$ This perception is not baseless; the plaintiff to a defamation claim bears no burden of proving that the imputations complained of are false,,${ }^{11}$ nor do they need to provide evidence of harm. ${ }^{12}$

The context in which issues of triviality arise is best highlighted through a few examples. In Ecclestone v Telegraph Media Group Ltd a young socialite and model, soon to launch her own fashion label, was misquoted by The Telegraph as saying she did not "have much time for" prominent vegetarians Annie Lennox and the McCartney family, implying (arguably at least) that she was dismissive of vegetarians. ${ }^{13}$ The Telegraph was sued again the following year in Thornton $v$

5 Opai v Culpan [2017] NZHC 1036, [2017] NZAR 1142 at [81].

$6 \quad X v$ Attorney-General of New Zealand (No 2) [2017] NZHC 1136, [2017] NZAR 1365 at [19].

7 Sellman v Slater, above n 1, at [59]; and Moodie v Strachan [2013] NZHC 1394 at [59].

8 Opai v Culpan, above n 5, at [63]; and Deliu v Hong [2013] NZHC 735 at [159].

9 Opai v Culpan, above n 5, at [89].

10 Ali Romanos "Is New Zealand the Libel World's most plaintiff friendly jurisdiction?" (25 August 2015) Inforrm's Blog <https://inforrm.org>; and Ware v Johnson [2014] NZHC 892 at [46].

11 Defamation Act 1992, s 8 .

12 Rosemary Tobin and David Harvey New Zealand Media and Entertainment Law (Thomson Reuters, Wellington, 2017) at 178 .

13 Ecclestone v Telegraph Media Group Ltd [2009] EWHC 2779 (QB). 
Telegraph Media Group $L t d,{ }^{14}$ in response to a negative book review. The review alleged that the writer, Thornton, engaged in copy approval, a disapproved of journalistic practice which allows interviewees to read what is written about them and alter it. The Queen's Bench division of the High Court in both cases considered whether the alleged meanings were sufficiently serious to meet the threshold for defamation. Both claims failed. ${ }^{15}$

In Jameel v Dow Jones \& Co Inc, The Wall Street Journal published a story online announcing the existence of a list naming donors to al-Qaeda. The story included a hyperlink to the list, which named Jameel. Prima facie, Jameel had been seriously defamed by being falsely linked to a terrorist organisation. However, after the publisher proved that the list was only accessed by five people in England (three of whom were Jameel's associates), the Court of Appeal struck out the claim as an abuse of process.

Each scenario raises the same question: is it justifiable to block the claimant's right to seek redress through the courts, either because allowing the claim would be a disproportionate infringement upon the defendant's right to freedom of expression, or because the claim is unworthy of the judicial resources it would demand? The volume of cases in which Jameel ${ }^{16}$ and Thornton $^{17}$ have been

14 Thornton v Telegraph Media Group Ltd [2010] EWHC 1414, [2011] 1 WLR 1985 (QB).

15 Ecclestone v Telegraph Media Group, above n 13, was actually delivered before Thornton v Telegraph Media Group, above n 14. In Thornton, above n 14, at [82], Tugendhat J cites Ecclestone, stating that Sharp J "did clearly apply a threshold of seriousness".

16 Cases in which Jameel has been successfully invoked include: Russell v Matthews [2016] NZDC 17743, which involved "indubitably defamatory remarks" communicated only to the claimant's father and a professional standards body, causing "infinitesimally small" reputational loss. Proceeding with the case would have demanded at least five days of preparation, a two day hearing (necessitating inconvenience to witnesses) and one day for the judge to write a judgment; Xv Attorney-General of New Zealand (No 2), above $\mathrm{n}$ 6, in which the claimant had reported being the victim of sexual assault and harassment during her time in the New Zealand Navy and subsequently had her image used in Navy's promotional posts on Facebook. The claimant, arguing defamation by innuendo, asserted that those who knew of her experiences with the Navy would perceive her to be hypocritical and unprincipled upon viewing the pictures. There was no evidence that anyone in that small group saw the material or, if they did, that X's reputation was damaged in that way; Kaschke v Osler [2010] EWHC 1075 (QB), in which the offending blog posts were largely comprised of material published on the plaintiff's own website, and the defendant had removed the offending post from his blog and published a reply from the plaintiff; and several cases where, like Jameel, publication was very limited, see for example Davison v Habeeb [2011] EWHC 3031, [2012] 3 CMLR 104 (QB) where a blog post was accessed by five people at most; McDonnell v Adair [2009] NIQB 93 where the only recipients were an associate of the defendant and four members of the claimant's camp; and Citation plc $v$ Ellis Whittam Ltd [2012] EWHC 764 (QB), where there was only one recipient.

17 Publications which have failed to meet the Thornton threshold include: minor criticisms about the quality of the plaintiff's work performance in Daniels v British Broadcasting Corp [2010] EWHC 3057 (QB); a Daily Mail article about public figure Nancy Dell'Olio, which referred to her as a "man-eater" and contained "insulting" references to her lifestyle, money and wealth in Dell'Olio v Associated Newspapers Ltd [2011] 
utilised demonstrate that blocking the claimant's access to the courts in such cases is not only justifiable, but necessary. However, the implementation of these principles in New Zealand requires careful consideration of how to balance the parties' competing rights; deserving claimants should not be faced with an insurmountable burden in an overzealous bid to protect free speech and court resources.

\section{NEW ZEALAND'S STATUTORY CONTEXT}

\section{A Defamation Act 1992}

Defamation law in New Zealand is largely grounded in common law. ${ }^{18}$ The Defamation Act 1992 refines some aspects of the tort (such as defences and remedies) but offers little guidance as to a requirement of harm beyond s 4 , which states that defamation is actionable "without proof of special damage," meaning the claimant is not required to show financial harm. The common law elements which a claimant must prove are as follows: ${ }^{19}$

(1) there must be a statement made containing a defamatory meaning (or 'sting') about the claimant;

(2) it must be published to one or more persons; and

(3) it must identify the claimant.

Damage to reputation is presumed at common law; the claimant does not need to supply proof. ${ }^{20}$ There is no legislative definition of defamatory meaning (element one), nor is there one definitive common law meaning, but the test articulated in the House of Lords decision Sim v Stretch is commonly used: the publication must "tend to lower the plaintiff in the eyes of right-thinking members of society generally". ${ }^{21}$ The adequacy of this test requires further consideration in light of Thornton, which suggests that it is an incomplete definition of defamatory meaning.

\section{B High Court Rules 2016}

Rule 15.1 of the High Court Rules 2016 governs the jurisdiction to strike out or stay a proceeding, in whole or in part. Where the Jameel principle is invoked, r 15.1(1)(d) permits the strike out of claims which are "otherwise an abuse of the process of the court". The Thornton principle can also be relevant

EWHC 3472 (QB); and an autobiography which suggested that the claimant employee sent "pompous messages" in Briggs v Jordan [2013] EWHC 3205 (QB).

18 Tobin and Harvey, above n 12, at 176.

19 At 177

20 Lachaux $v$ Independent Print Ltd (CA), above n 4, at [72].

21 Tobin and Harvey, above n 12, at 183, citing Sim v Stretch [1936] 2 All ER 1237 (HL) at 1240. The authors note that this is commonly supplemented with other tests, such as the "hatred, ridicule or contempt" test (Parmiter v Coupland (1840) 6 M \& W 105, 151 ER 340 (Exch)) and the "shun and avoid" test (Youssoupoff v MGM Pictures Ltd (1934) 50 TLR 581 (CA) at 587). 
during a strike out application if the defendant can prove that the claimant has no chance of successfully establishing that the tort occurred, engaging $r$ 15.1(1)(a) which permits the strike out of a claim which discloses no reasonably arguable cause of action.

\section{UNITED KINGDOM POSITION}

New Zealand defamation law has developed largely from United Kingdom precedent. Until the passage of the Defamation Act 2013, a twin track approach to eliminating trivial claims was used in the United Kingdom: either they could be struck out on a Jameel basis, or they could fail (at strike out or trial) for not meeting the Thornton threshold. The Defamation Act 2013, an attempt to clarify the law and strengthen its freedom of expression protections, ${ }^{22}$ enacted s 1(1), which provides that "a statement is not defamatory unless its publication has caused or is likely to cause serious harm to the reputation of the claimant." Part IV outlines the Jameel and Thornton principles, then discusses the change introduced by s 1 and how this change was responded to by the Court of Appeal in Lachaux $v$ Independent Print Ltd, the first appellate case to consider the new provision. It will be argued that $\mathrm{s}$ 1 was designed by Parliament to fuse the Jameel and Thornton approaches, which the Court ignored in Lachaux, instead holding that the section simply codified Thornton. The Lachaux decision was a product of necessity, borne from the conceptual difficulties with giving effect to the section's intended meaning.

\section{A Jameel v Dow Jones \& Co Inc}

The 2005 Court of Appeal decision of Jameel marked the first time an otherwise valid defamation claim was struck out on the basis that the claimant had suffered no real harm in the jurisdiction. As outlined in Part II, a hyperlinked document in the The Wall Street Journal named the claimant as a donor to al-Qaeda. During the proceedings the defendant produced evidence that only five people in England had accessed the document, three of whom were the claimant's associates. Despite the gravity of the allegations, the claim was struck out under the Civil Procedure Rules 1998 (UK) as an abuse of process on the basis that no "real or substantial tort" had been committed given the small number of readers. ${ }^{23}$ The Court considered that its responsibility to ensure that judicial resources are used proportionately required the strike out of defamation proceedings which do not serve the legitimate purpose of protecting the claimant's reputation. ${ }^{24}$ It also considered that the Human Rights Act 1998 (UK), which incorporated the freedom of expression protections in art 10 of the European Convention

22 Erik Descheemaeker "Three Errors in the Defamation Act 2013" (2015) 6 JETL 24 at 24

23 Jameel, above n 3, at [70]-[71].

24 At [54] and [71]. 
on Human Rights into domestic legislation, ${ }^{25}$ required strike out in such cases. ${ }^{26}$ The Court concluded that even if the claimant succeeded, "[t]he cost of the exercise will have been out of all proportion to what has been achieved." 27

That phrase has been interpreted as establishing a proportionality principle which allows claims to be struck out if they will cost disproportionately more in court resources than is justified by the amount in damages that the claimant stands to gain. ${ }^{28}$ Others contend that the "disproportionality" question asks whether the claim is a disproportionate infringement on the defendant's right to freedom of expression. ${ }^{29}$ While neither interpretation is incorrect, to take either as the complete ratio of the judgment is an oversimplification. The touchstone requirement of the Jameel principle is the absence of harm: to use the wording of the judgment, the absence "of a real and substantial tort" ${ }^{30}$ It is a necessary component of a finding that no real and substantial tort has occurred that the claim would incur disproportionate costs, but this is inadequate in itself to justify strike out. ${ }^{31}$ Similarly, if the claim appears to be a disproportionate infringement upon the defendant's freedom of expression this points to the absence of a real and substantial tort, but may not be sufficient in itself as proof that only minimal harm has occurred.

\section{B Thornton v Telegraph Media Group Ltd}

In 2010, the Queen's Bench Division of the High Court delivered judgment in Thornton. The defendants' application for summary judgment was successful on the grounds that the words, which accused Thornton of copy approval, were not capable of being defamatory because they did not impute sufficiently reprehensible conduct. However, it was the subsequent discussion of a threshold of harm which went on to gain traction. The Judge canvassed numerous commonly used defamatory meaning tests, and observed that it was explicit or implicit in those tests that the statement must have a tendency to cause the claimant to suffer some sort of adverse consequences. ${ }^{32}$ Tugendhat $\mathrm{J}$ held that

25 Convention for the Protection of Human Rights and Fundamental Freedoms (as amended by Protocols No 11 and 14) 213 UNTS 221 (opened for signature 4 November 1950, entered into force 3 September 1953).

26 Jameel, above $\mathrm{n} 3$, at [55].

27 At [69].

28 Matthew Collins Collins on Defamation (Oxford University Press, Oxford, 2014) at [7.46]; Ware v Johnson, above n 10, at [40]; and Opai v Culpan, above n 5, at [16]. Support in Jameel, above n 3, for this reading of "proportionality" can be found at [54] and [71].

29 Richard Parkes and others Gatley on Libel and Slander (12th ed, Sweet \& Maxwell, London, 2017) at [2.3].

30 Jameel, above n 3, at [70], as cited in Heather Rogers and others Duncan and Neill on Defamation (4th ed, LexisNexis, 2015) at [4.02].

31 Mardas v New York Times Co [2008] EWHC 3135, [2009] EMLR 152 (QB) at [11]; and Lait v Evening Standard Ltd [2011] EWCA Civ 859, [2011] 1 WLR 2973 at [42].

32 Thornton, above n 14, at [51] and [85]. 
a threshold of seriousness therefore applies to the meaning of a statement. ${ }^{33}$ Accordingly, the threshold test articulated by the Judge was whether the statement "substantially affects in an adverse manner the attitude of other people towards ... [the claimant], or has a 'tendency' so to do."34 Similarly to the Court in Jameel, his Honour considered that the threshold was required to secure conformity with the Human Rights Act. ${ }^{35} \mathrm{He}$ also observed that the threshold was consistent with the presumption of damage; if a statement is not likely to substantially adversely affect attitudes towards the claimant, it would be illogical to presume that the claimant has suffered harm from it. ${ }^{36}$

Further, Tugendhat $\mathrm{J}$ considered that a threshold was necessary in light of the principle developed by Jameel. ${ }^{37}$ On one view the threshold is simply an aspect of the Jameel principle because a claim in respect of a trivial statement which has caused no real harm is equally at risk of being struck out under Jameel due to lack of a real and substantial tort. ${ }^{38}$ However, this is not justification for melding the two distinct principles. Thornton places a burden of proof on the claimant, unlike Jameel. Additionally, the Thornton threshold has a far narrower scope than Jameel: it is concerned only with the meaning of the statement.

There is nothing in the judgment to suggest that Tugendhat $\mathbf{J}$ considered that an analysis of whether the threshold is met requires an examination of factors external to the publication, such as the number of publishees. ${ }^{39}$ Tugendhat $\mathbf{J}$ incorporated the words "or has a 'tendency' so to do" in his formulation of the test to ensure that claimants were not required to prove that there had in fact been an effect upon them. ${ }^{40}$ The wording of the first part of the test ("substantially affects") suggests that claimants are not prohibited from producing such evidence, but they would only need to do so if there was doubt about whether the words were, on their face, defamatory. Arguably, Tugendhat J simply articulated a threshold of seriousness which was already inherent in the defamatory meaning

33 At [89].

34 At [96].

35 At [89].

36 At [93].

37 At [89].

38 Alastair Mullis and Andrew Scott "Tilting at Windmills: The Defamation Act 2013" (2014) 77 MLR 87 at 105 .

39 This reading of Thornton is supported by Collins, above n 28, at [6.44]; Opai v Culpan (No 2), above $\mathrm{n}$ 1, at [32]; and Lachaux v Independent Print Ltd [2015] EWHC 2242, [2016] QB 402 (QB) at [50] [Lachaux v Independent Print Ltd (HC)].

40 Thornton v Telegraph Media Group, above n 14, at [92]. 
element, ${ }^{41}$ without overriding existing defamatory meaning tests. ${ }^{42}$ Nonetheless, the "threshold of seriousness" terminology quickly took hold.

\section{Defamation Act 2013 (UK), s 1}

Section 1 of the Defamation Act 2013 states that "a statement is not defamatory unless its publication has caused or is likely to cause serious harm to the reputation of the claimant." The explanatory note for s 1 states that the section "builds on" Thornton and Jameel, but "raises the bar". ${ }^{43}$ This leaves a crucial question unanswered: was s 1 intended to leave two distinct principles in play, or to amalgamate Thornton and Jameel? The latter view is better supported by parliamentary discussion and academic writing on the issue, ${ }^{44}$ despite some statements to the contrary. ${ }^{45}$ Section 1 was not intended to completely eradicate the first element of the tort (the requirement for a claimant to prove the "sting" of the statement using the common law tests), ${ }^{46}$ rather it was intended to replace Thornton and Jameel by adding a preliminary element to be proved by the claimant. This new element would require a holistic examination of whether in all the circumstances serious harm has actually occurred or is likely to occur.

During debate on the Bill which would become the 2013 Act, Lord McNally stated not only that the Bill would "raise the bar to a modest extent", but also that "a wide range of circumstances may be relevant in determining whether the serious harm test is met". ${ }^{47}$ Similarly, the Joint Committee

41 This was the conclusion reached by Gould in Kim Gould "Locating a 'Threshold of Seriousness' in the Australian Tests of Defamation" (2017) 39 Syd LR 333. See also Lesses v Maras [2017] SASCFC 48, (2017) 128 SASR 292 at [125].

42 It is clear that Tugendhat $\mathrm{J}$ did not intend to override the existing tests for three reasons: firstly, he does not purport to do so. Secondly, if he had, it would have the illogical result that any statement could be defamatory if, for some reason, it substantially affected attitudes towards the claimant, even if the statement was incapable of being defamatory at common law. Thirdly, Tugendhat J applied such tests in his subsequent judgments. See for example Waterson v Lloyd [2011] EWHC 3197 (QB) at [26]; and Miller v Associated Newspapers Ltd (No 2) [2011] EWHC 2677 (QB) at [33]. Accordingly, while external factors are not relevant to a Thornton analysis, the court can still consider contextual factors which would ordinarily be considered as part of the defamatory meaning analysis. This includes surrounding words and the nature of the publication itself: see Tobin and Harvey, above n 12, at 180-181 for a discussion of the role of context in the defamatory meaning analysis.

43 Defamation Act 2013 (UK), s 1 (explanatory note) at 11.

44 It is also the interpretation taken by Associate Judge Bell in Opai v Culpan (No 2), above n 1, at [75].

45 House of Lords and House of Commons Joint Committee on the Draft Defamation Bill Draft Defamation Bill (HL Paper 203 HC 930-I, 19 October 2011) at [27].

46 See Collins, above n 28, at [6.50]-[6.56], which provides a compelling argument as to why s 1 cannot have been intended to overrule the common law tests. The point is also made in Lachaux $v$ Independent Print Ltd (CA), above n 4, at [39].

47 (17 December 2012) 741 GBPD HL 422-423. 
recommended that the judge should consider the context, including rapid corrections or apologies. ${ }^{48}$ The consideration of a wide range of circumstances (including corrections and apologies) is in itself a significant raising of the Thornton bar, given that Thornton was concerned only with the meaning of the statement. However, it would have been clearer that Parliament intended for wider circumstances to be considered if the chosen wording was "a statement is not actionable" rather than "not defamatory". ${ }^{49}$ The language of actionability is more consistent with Jameel, which accepts that a statement can be simultaneously defamatory and not actionable.

An analysis of academic writing published during and shortly after the passage of s 1 reveals a widespread understanding that s 1 went beyond Thornton to incorporate the wider considerations characteristic of a Jameel analysis. Collins on Defamation, stating the law as at September 2013, argued that it was clear s 1 went beyond codifying Thornton, enabling claims to be struck out where "having regard to all the circumstances, there is so little at stake that the claim ought not to be permitted to proceed." ${ }^{50}$ This is a ground for strike out which, prior to the Act, would have come under Jameel jurisdiction. The relevant circumstances suggested by Collins included the extent of publication, the nature of the recipients, any evidence as to whether or not recipients believed the allegations and whether there was an apology or correction. ${ }^{51}$ Collins noted that serious harm could be inferred in some cases, at least when determining whether the statement is "likely to" cause serious harm, but the inference would not be drawn on the basis of the words alone; the manner and extent of publication would also be relevant. ${ }^{52}$ The factors listed as relevant by Collins, and the need to consider the manner and extent of publication, are consistent with a Jameel inquiry.

Duncan and Neill on Defamation observed that while the meaning of s 1 was "open to debate",53 in the authors' view the section required two prongs to be satisfied: firstly, the publication must convey a meaning that has a tendency to cause serious harm to reputation and secondly, it must be shown that in the circumstances (including the extent and status of the publication, the nature of its audience and any correction or apology), serious harm has been caused or is likely to be caused. On this approach, the question of whether the publication caused or was likely to cause serious harm again goes beyond a Thornton-style analysis of the meaning. The authors considered that in light of their approach, it was "doubtful" that the common law presumption of damage to reputation had survived. ${ }^{54}$ At the time

48 Joint Committee on the Draft Defamation Bill, above n 45, at [30].

49 See Collins, above n 28, at [7.48]; and Parkes and others, above n 29, at [2.5].

50 Collins, above n 28, at [7.44]

51 At [7.30]-[7.34].

52 At [7.30].

53 Rogers and others, above n 30, at [1.11]. Stating the law as at November 2014.

54 At [4.06]. 
the text was published there had been only one judgment at High Court level which considered s 1: Cooke v MGN Ltd. ${ }^{55}$ The authors observed that as per Bean $\mathrm{J}$ in Cooke, serious harm could be inferred in cases of "grave" allegations. ${ }^{56}$

\section{$D$ Lachaux v Independent Print Ltd}

In a decision as heavily praised as it was criticised, ${ }^{57}$ the Court of Appeal in Lachaux ignored s 1 's intended effect. ${ }^{58}$ The Court held that s 1 is essentially a codification of Thornton, and that an inference of serious harm can be drawn where the statement conveys a serious imputation. ${ }^{59} \mathrm{~A}$ defendant could seek to rebut the inference at a strike out application or present their arguments at trial. ${ }^{60}$ It was acknowledged that "where necessary or appropriate" the context in which the words are used could also be relevant, for example, if the words appeared in a newspaper or widely accessed blog. ${ }^{61}$ The Court held that the Jameel jurisdiction could still be relevant in rare cases where s 1 appeared satisfied but the claim was disproportionate for other reasons. ${ }^{62}$

Although the replacement of the common law language of "tendency" with the "is likely to" terminology in s 1 was a considered choice by Parliament, ${ }^{63}$ the Court also held that "is likely to" means "tendency". ${ }^{64}$ This decision is significant because the terms are distinct; whilst "tendency" permits a more abstract analysis, determining whether a publication "is likely to" cause serious harm arguably requires a court to consider whether the publication might, on the particular facts, cause

55 Cooke v MGN Ltd [2014] EWHC 2831, [2015] 1 WLR 895 (QB).

56 Rogers and others, above n 30, at [4.10], citing Cooke v MGN Ltd, above 55. The example given in Cooke was an accusation in a national newspaper of terrorism or paedophilia.

57 Greg Callus "Defendants should not be gleeful at prospect of Supreme Court allowing appeal on defamation test in Lachaux case" Press Gazette (online ed, United Kingdom, 10 April 2018); Iain Wilson and Tom Double "Business as usual? The Court of Appeal considers the threshold for bringing a libel claim in Lachaux $v$ Independent Print Ltd" (16 September 2017) Inforrm's Blog <https://inforrm.org>; Michael Cross "Landmark appeal judgment dents libel threshold hopes" The Law Society Gazette (online ed, United Kingdom, 12 September 2017); and Nicola Cain "Seriously limiting serious harm" (12 September 2017) RPC <www.rpc.co.uk>.

58 The decision has been appealed to the Supreme Court and was heard by the Court in November 2018.

59 Lachaux v Independent Print Ltd (CA), above n 4, at [70].

60 At [69]-[70].

61 At [73].

62 At [79] and [82].

63 Collins, above n 28, at [7.27].

64 Lachaux v Independent Print Ltd (CA), above n 4, at [46]-[50]. 
actual harm in the future. ${ }^{65}$ As observed in Gatley on Libel and Slander, the decision to read "is likely to" as "tendency" effectively renders the first part of s 1(1) redundant; why would a claimant attempt the more difficult task of proving the statement has caused serious harm, when they could simply point to the tendency of the statement to do so, as demonstrated by the words alone? ${ }^{66}$

The interpretation of s 1 as a straightforward codification of Thornton (but with "substantially" changed to "serious") is inconsistent with Parliament's intention, a point which has been made forcefully by commentators. ${ }^{67}$ Accepting that the Court knowingly departed from Parliament's intention, the natural question must be: why? This article argues in Part VI that fusion of the two conceptually distinct approaches opposes the long-standing presumption of damage and creates an unreasonably high burden for claimants. The Lachaux judgment reflects a Court desperate to ensure the law of defamation remains workable.

\section{NEW ZEALAND'S CASE LAW: APPROACH TO THORNTON $A N D$ JAMEEL}

Following CPA Australia Ltd v New Zealand Institute of Chartered Accountants and Sellman v Slater, the Thornton threshold has established an initial foothold in New Zealand, albeit on insecure ground. It is yet to face appellate scrutiny and thus far the courts have not clarified precisely what the threshold requires or which party bears the burden of proof. New Zealand judges have also varied in their willingness to apply Jameel. Although it has been applied twice at High Court level, ${ }^{68}$ in other cases judges have offered multiple reasons for its inapplicability. These include: that the case was primarily concerned with a jurisdictional issue and its precedent should not be extended further; that New Zealand does not have an equivalent to the Civil Procedure Rules (UK) nor is it a party to the European Convention on Human Rights (the Convention which informed the Human Rights Act); ${ }^{69}$ and that it threatens the right of access to justice. The following discussion highlights that it is only

65 Richard Parkes and others Gatley on Libel and Slander (12th ed, 2nd supplement, Sweet \& Maxwell, London, 2017) at [2.6]. However, the authors anticipated that in most cases where a claim would have survived the "tendency" test under Thornton, the statement would also satisfy s 1(1).

66 At [2.6].

67 See Cain, above n 57, who described it as: "a disappointing and regressive judgment for defendants, which contrasts with the indications given by Parliament as to how they envisaged the new section would protect defendants"; and Jonathan Coad "Landmark appeal judgment dents libel threshold hopes" The Law Society Gazette (online ed, United Kingdom, 12 September 2017).

$68 X v$ Attorney-General (No 2), above n 6; and Opai v Culpan, above n 5. It has also applied by the District Court in Craig v Stiekema [2017] NZDC 15914, [2018] DCR 291 (this was later overturned by the High Court because its application was unsupported by the facts); and Russell v Matthews, above n 16.

69 Human Rights Act 1998 (UK), s 1. See the Convention for the Protection of Human Rights and Fundamental Freedoms, above n 25 . 
the last of these arguments which carries any significant weight, and on balance, this concern is outweighed by the numerous advantages of adopting Jameel in New Zealand.

\section{A Jameel in New Zealand}

\section{The issue in Jameel was jurisdictional}

The first New Zealand case to consider Jameel was Karam v Parker, a claim brought by Joe Karam regarding posts online criticising his involvement with David Bain. Associate Judge Sargisson distinguished Jameel due to dissimilar facts (the posts in Karam were read by a "significant number of people"), ${ }^{70}$ but she gave two broader grounds for doubting Jameel's applicability in New Zealand. Her Honour's first ground was that the primary issue in Jameel was whether the case should be tried in the United Kingdom or another jurisdiction. ${ }^{71}$ The numerous cases which have applied Jameel in the United Kingdom ${ }^{72}$ demonstrate that this is an overly narrow reading of the Jameel ratio and the wording of the judgment does not support such restricted application. ${ }^{73}$ This ground carries no weight following Katz J's Opai v Culpan judgment, which confirmed that the reasoning in Jameel is not so confined. ${ }^{74}$

\section{The Civil Procedure Rules are dissimilar to New Zealand's High Court Rules 2016}

Associate Judge Sargisson's second ground for distinguishing Jameel in Karam was the "different legislative context" of New Zealand. ${ }^{75}$ This argument was picked up in Deliu v Hong, the only clear rejection of Jameel in New Zealand case law. Associate Judge Osborne in Deliu canvassed the differences between New Zealand's High Court Rules and the United Kingdom's Civil Procedure Rules, noting that the Civil Procedure Rules have the overriding objective of dealing with cases "justly", ${ }^{76}$ which expressly includes proportionality considerations. ${ }^{77}$ By comparison, concepts of

70 Karam v Parker HC Auckland CIV-2010-404-3038, 29 July 2011 at [55].

71 At [53].

72 See n 16.

73 One way to test the theory is to consider: was the existence of a more appropriate jurisdiction in which Jameel could bring his case crucial to the Court's decision to strike out the claim? Several paragraphs in Jameel, above n 3, suggest it was not, for example at [56], the Court notes that Duke of Brunswick v Harmer (1849) 14 QB 185, 117 ER 75 (KB) (which did not involve any jurisdictional issue) would, if heard in modern times, be struck out as an abuse of process. See also [57] and [68]-[71].

74 Opai v Culpan, above n 5, at [22]. Associate Judge Sargisson later acknowledges this herself in Ware v Johnson, above n 10, at [46].

75 Karam v Parker, above n 70, at [54].

76 Rule 1.1.

77 Deliu v Hong, above n 8, at [182], citing r 1.1(2)(c). 
proportionality are not "spelt out" in the High Court Rules. ${ }^{78}$ The discussion was obiter, because the Judge held that even if Jameel was applicable in New Zealand, he would not have applied it given that one of the parties stood to receive substantial damages. ${ }^{79}$

Ronald Young J's judgment in Moodie v Strachan was released two months after that rejection of Jameel. Although holding that Jameel was inapplicable on the facts, his Honour could: ${ }^{80}$

... see no reason why New Zealand courts would not be prepared to stay (or strike out) civil proceedings

that cannot serve the legitimate purpose of the cause of action pleaded.

Contrary to Associate Judge Osborne, Ronald Young J located similarities between the Civil Procedure Rules and New Zealand's High Court Rules, observing that the High Court Rules "have, as their express object, the just, speedy and inexpensive determination of proceedings." 81

When Associate Judge Sargisson confronted the issue four years later in Ware v Johnson, ${ }^{82}$ her views were more aligned with Ronald Young J's analysis. She considered that the High Court Rules were sufficiently similar to the Civil Procedure Rules "to justify striking out proceedings that cannot serve the legitimate purpose of the cause of action pleaded." 83 Were it not for the availability of a qualified privilege defence, her Honour "could well" have applied Jameel. ${ }^{84}$ The approach taken by Ronald Young J and Associate Judge Sargisson is preferable to Associate Judge Osborne's more rigid reading of New Zealand's High Court Rules. The absence of proportionality as an express overriding objective of the High Court Rules is not evidence of its irrelevance. A holistic interpretation of the Rules is more aligned with the policy goal of sensibly allocating court resources.

In Opai v Culpan, the first High Court case to apply Jameel, Katz J also considered that there was sufficient emphasis placed on proportionality in New Zealand's High Court Rules. ${ }^{85}$ Her Honour considered that the general trajectory of recent procedural developments "has been to improve the

78 At [182].

79 At [194]

80 Moodie v Strachan, above $\mathrm{n}$ 7, at [60]. This wording should not be overanalysed. The corollary of there being no real and substantial tort is that the claim cannot serve the legitimate purpose of vindicating reputation, because there is nothing to vindicate. Conversely, it is difficult to imagine a claim which does not serve the legitimate purpose of vindicating reputation where there is a real and substantial tort. Accordingly, the "legitimate purpose" wording should not be interpreted as changing the core of the Jameel principle: the lack of a real and substantial tort.

81 At [58], citing r 1.2.

82 Ware v Johnson, above n 10

83 At [46].

84 At [47].

85 Opai v Culpan, above n 5, at [48]. 
overall efficiency and cost-effectiveness of litigation." ${ }^{86}$ Opai concerned a claim brought by a police employee regarding workplace documents written by her supervisor, Culpan, which Opai characterised as a "[m]alevolent campaign to vilify." ${ }^{87}$ Associate Judge Bell, who initially heard the case, struck out elements of Opai's claim which he found to be Jameel disproportionate. ${ }^{88} \mathrm{Katz}$ J, who reviewed that decision in 2016, confirmed that aspects of the claim could be struck out on Jameel grounds. ${ }^{89}$

\section{The Human Rights Act 1998 (UK) is dissimilar to the New Zealand Bill of Rights Act 1990}

In Opai, the plaintiff also submitted that Jameel is inapplicable in New Zealand because it drew on the Human Rights Act, a statute which has no equivalent in New Zealand. ${ }^{90}$ Katz J succinctly disposed of this argument by reference to s 14 of the New Zealand Bill of Rights Act 1990 (NZBORA), which, like the Human Rights Act, recognises the right to freedom of expression. ${ }^{91}$ After comparing the two Acts, Katz J concluded that the NZBORA placed a similarly high value on freedom of expression to the Human Rights Act. ${ }^{92}$ Her Honour observed that the importance of this right has gained increased recognition in recent years, and linked this with the growing desire to strike out trivial claims. ${ }^{93}$

Section 5 of the NZBORA does permit the limitation of NZBORA rights where such limitations are "demonstrably justified in a free and democratic society." The censure of defamatory statements which have caused the claimant substantial harm to reputation exemplifies a justifiable limitation on the right to freedom of speech. The same cannot be said of claims regarding publications which have caused insignificant harm. This is particularly pertinent where the speech in respect of which the claimant is suing can be classed as significant. Speech can be viewed as existing on a spectrum, with political commentary typically afforded the highest significance, and abuse and gossip about private facts at the other end. Because s 5 mandates a balancing exercise, NZBORA affords greater protection to significant speech. ${ }^{94}$ The censure of significant speech is more likely to be viewed as a

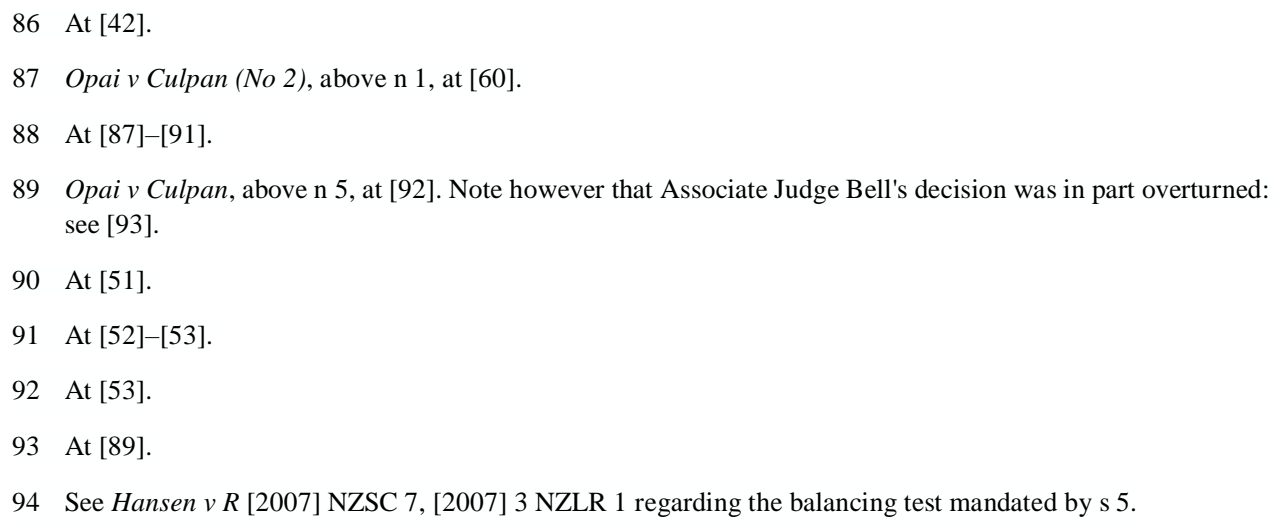


disproportionate infringement on the defendant's freedom of expression, which adds weight to the defendant's assertion that there is no real and substantial tort. Accordingly, Jameel applications made in respect of significant speech may be viewed more favourably. ${ }^{95}$

\section{Jameel threatens access to justice}

The better arguments for exercising caution with Jameel are based on the threat posed to the right to access justice. Even Jameel's supporters have acknowledged this danger. ${ }^{96}$ This concern was raised by Associate Judge Osborne in Deliu, who considered that adopting Jameel would be an unprecedented departure from "the traditional approach" to access to justice in New Zealand. ${ }^{97}$ The issue was taken up again by Palmer J in Sellman. The Sellman judgment, released several months following Opai, concerned proceedings brought against Cameron Slater and his associates regarding blog posts which made various allegations about the claimant public health professionals. Palmer $\mathbf{J}$ demonstrated significant reluctance to approve of Jameel and expressed concern about the jurisdiction being "routinely" utilised by the courts, ${ }^{98}$ but he did accept that it was "conceivable" that the jurisdiction could be used in "extreme circumstances". 99

The concerns raised by Palmer J and Associate Judge Osborne are worthy of consideration. New Zealand places "high constitutional value" on the right of individuals to access the courts, ${ }^{100}$ so where this is threatened, the conceptual basis for doing so must be scrutinised. Palmer J highlighted that rule of law concerns are also engaged, stating: ${ }^{101}$

... the rule of law requires that, except in the rarest of circumstances where it is clearly justified, the courts themselves should not override the right of an individual to access the courts to vindicate their actionable legal rights; society's collective financial interests notwithstanding.

The Jameel doctrine is grounded in abuse of process and tied to an analysis of whether the claim is worthy of the expense it would incur. The primary question is of costs to the court, but the time and

95 See Lait v Evening Standard Ltd, above n 31, in which the Evening Standard reported substantial expenditure incurred by the claimant MP. The Court of Appeal upheld the High Court's application of Jameel and noted at [42] that freedom of expression considerations are particularly important, "where a defence of honest comment is advanced by a responsible - I emphasise the adjective - journalist."

96 Opai v Culpan, above n 5, at [64]; and Ware v Johnson, above n 10, at [48].

97 Deliu v Hong, above n 8, at [192].

98 Sellman $v$ Slater, above n 1, at [60].

99 At [59].

100 At [60].

101 At [61]. 
costs incurred by the parties is also relevant. ${ }^{102}$ This inquiry is arguably at odds with the conceptual foundations of defamation as a tort, and the importance placed upon restoration of reputation. Claimants in a defamation case may have little interest in monetary gain, rather they seek the opportunity to be publicly vindicated. ${ }^{103}$ It also creates the potential for the court to pick apart a claim, weighing the value of each pleading against the potential cost to the court to determine whether it is "worth the candle"104 - an exercise which seems intuitively odd. In light of this, it is sensible to question whether it is appropriate to strike out otherwise actionable claims because the stakes appear low to the court. That the claimant has invested the time and effort necessary to file the proceedings demonstrates that to the claimant, the stakes are clearly high enough.

\section{Should Jameel be endorsed in New Zealand?}

The existence of $\mathrm{r}$ 15.1(1)(d) demonstrates that Parliament could envision circumstances where the strike out of an otherwise actionable claim as an abuse of process would be "clearly justified", 105 to use Palmer J's phrasing. ${ }^{106}$ This article argues that a defamation claim in respect of non-existent or trivial harm exemplifies such a case, and the justifications for endorsing Jameel in New Zealand are numerous.

Firstly, allowing a trivial claim to proceed does not give appropriate recognition to the defendant's NZBORA rights. It is true that in such cases the defendant may succeed with an alternative defence (such as truth or honest opinion), or if they lose, they may only have to pay nominal damages. But as noted by Katz $\mathrm{J}$ in Opai, citing Lonzim Plc v Sprague, "the fact of being sued at all is a serious interference with freedom of expression", ${ }^{107}$ hence the desire to have unworthy defamation claims struck out at the earliest possible stage. A requirement that a substantial tort has been committed before the court will hear a defamation claim is a reasonable limitation on the claimant's right to access the courts in favour of the defendant's right to freedom of speech.

Allowing the proceedings to continue is not necessarily in the claimant's interests either. Claimants may bring trivial claims because they are unaware of how minimal the actual harm to their

102 At [59]; and Ware v Johnson, above n 10, at [40].

103 Deliu v Hong, above n 8, at [192].

104 Jameel, above n 3, at [69].

105 As noted in Part III(B), r 15.1(1)(d) of the High Court Rules 2016 allows claims to be struck out which are "an abuse of the process of the court".

106 Sellman v Slater, above $\mathrm{n}$ 1, at [61].

107 Lonzim Plc v Sprague [2009] EWHC 2838 (QB) at [33] per Tugendhat J, as cited in Opai v Culpan, above n 5 , at [53]. 
reputation is, ${ }^{108}$ or because they are unable to objectively assess the actual harm to their reputation and perceive it as worse than it is. ${ }^{109}$ In such cases, it is doubtful whether the court does the claimant any favours by allowing the claim to proceed, at great cost to him or her, especially given that this will likely bring greater attention to the offending statements. ${ }^{110}$ Even a successful claimant may walk away out of pocket due to exorbitant legal costs. ${ }^{111}$ Conversely, if the claim was doomed to fail, at least a Jameel strike out puts an expeditious end to the claimant's expenses.

Further, it is not only the parties whom the court must consider. Although it would not be justified to exercise the Jameel jurisdiction on the basis of disproportionate costs alone, it is certainly a factor worth considering. Defamation trials bring significant cost to the courts (and, by extension, the public), a cost which is difficult to justify where the proceedings are being used to air objectively petty grievances of which no real harm has resulted. Additionally, while a Jameel strike out does impinge upon the claimant's right to access the courts, putting a prompt end to trivial claims enhances access to the courts generally by allowing for more efficient use of court resources. ${ }^{112}$

Finally, there are no grounds to suggest that if the Jameel principle receives unequivocal endorsement from an appellate court, it will be "routinely" invoked. ${ }^{113}$ All judges who have considered Jameel have emphasised that strike out jurisdiction is to be exercised cautiously, particularly where the claimant has a prima facie arguable case. ${ }^{114}$ Trivial claims are the minority, perhaps owing to the significant investment of time and money which bringing a claim requires. They will grow rarer still if claimants know that courts will strike them out. Accordingly, while the jurisdiction should only be utilised in appropriate cases, there is no need for excessive reluctance where its application is supported by the facts. The Jameel jurisdiction is a valuable tool when such cases arise.

Jameel gives greater priority to freedom of expression rights and goes some way to correcting the balance of a plaintiff-friendly tort. It does not create an unfair hurdle for claimants, rather it appropriately places the burden on the defendant to prove that no substantial tort has been committed. As the facts of Jameel illustrate, it is typically the defendants who will be in the best position to supply

108 This was arguably the case in Jameel, above n 3: the Court doubted at [38] that Jameel would have brought the claim had he known that dissemination was so limited in England.

109 CPA Australia Ltd v New Zealand Institute of Chartered Accountants, above n 1, at [114].

110 At [116].

111 Opai v Culpan, above n 5, at [81].

112 At [63].

113 At [68].

114 Moodie v Strachan, above n 7, at [60]; Opai v Culpan (No 2), above n 1, at [78]; Opai v Culpan, above n 5 , at [64] and [68]; Russell $v$ Matthews, above n 16, at [12]; Xv Attorney-General of New Zealand (No 2), above n 6, at [19]; and Craig v Stiekema [2018] NZHC 838, [2018] NZAR 1003, at [35] [Craig v Stiekema (HC)]. 
evidence, for example regarding the number of people who have accessed the statements. Therefore the burden is correctly placed. ${ }^{115}$ The judiciary is fully cognisant of the need to only use a tool which restricts the claimant's right to access the courts in appropriate cases and Palmer J's scepticism of the principle could invite unwarranted judicial hesitancy. Endorsement of the doctrine at appellate level is therefore desirable to cement its grounding in New Zealand law. ${ }^{116}$

\section{B Thornton in New Zealand}

CPA Australia Ltd and Sellman are the only New Zealand cases which explicitly address why the Thornton threshold should apply in New Zealand. Associate Judge Bell's Opai decision applied the Thornton defamatory meaning threshold without analysing why it applied in New Zealand. ${ }^{117}$ Fitzgerald J's High Court judgment in Craig $v$ Stiekema could be read as an endorsement of Thornton but her Honour disclaimed that she had no "concluded view."118

Dobson $\mathrm{J}$ in CPA Australia Ltd endorsed the application of a harm threshold in New Zealand because his Honour considered that it gave greater protection to freedom of expression rights enshrined in s 14 of NZBORA. ${ }^{119}$ Dobson J did not directly address Jameel and, unfortunately, the judgment confused the Thornton and s 1(1) thresholds. ${ }^{120}$ Whilst ostensibly endorsing Thornton, Dobson J referred to "serious harm" rather than "substantial harm" and concluded that the approach articulated in Gatley on Libel and Slander "appears appropriate." ${ }^{121}$ The Gatley excerpt referred to is not a straightforward restatement of the Thornton threshold, but a discussion of multiple United Kingdom cases. Citing Cammish v Hughes, ${ }^{122}$ the Gatley authors state that satisfaction of the harm

115 This was noted by Palmer J in Sellman v Slater, above n 1, at [65] (although it was in the context of the Thornton principle).

116 Should the issue come before an appellate court, the court should also confirm whether the defendant submitting a Jameel application can produce evidence of any external factors, or whether this is circumscribed. The author submits that any evidence which speaks to whether there is a real and substantial tort should be permitted. This reflects the approach in Opai v Culpan (No 2), above n 1, at [75]. On this view, evidence that the claimant already had a poor reputation, that the statement was not believed by the publishees, or that it was published only to the claimant's friends, could be relevant (though not necessarily decisive) because it may point to the absence of a real and substantial tort. Because there is existing case law holding that these details are not relevant to whether defamation has occurred, such as Hough v London Express Newspaper Ltd [1940] 2 KB 507 (CA), explicit clarification is desirable.

117 Opai v Culpan (No 2), above n 1, at [32]. Unfortunately the point was not picked up in Katz J's review, which focused more on Jameel.

118 Craig v Stiekema (HC), above n 114, at [51]-[52].

119 CPA Australia Ltd v New Zealand Institute of Chartered Accountants, above n 1, at [115].

120 This point was also made by Gould, above $\mathrm{n} 41$.

121 CPA Australia Ltd v New Zealand Institute of Chartered Accountants, above n 1, at [120].

122 Cammish v Hughes [2012] EWCA Civ 1655 at 40. 
threshold is a "multi-factorial question" which "will require the court to consider matters such as... the status and number of publishees and whether the allegations were believed, [and] the status of the publisher". ${ }^{123}$ This article submits that those factors are better considered under a Jameel analysis. ${ }^{124}$ Accordingly, although Dobson J's endorsement of Thornton is cause for celebration, the confusion of Thornton with the s 1 threshold renders the judgment of limited usefulness. In any case, the statements were obiter because CPA Australia's claim failed on a different ground.

The next case to consider Thornton was Sellman (the facts of which are discussed above). Palmer $\mathrm{J}$ considered that a minimum threshold of harm to reputation applied, and that this method of shaping defamation law was preferable to Jameel. ${ }^{125}$ Despite citing Thornton as authority, the harm threshold conceptualised by Palmer J was a vastly watered-down approach. Rather than placing a burden on the claimant to show that the statement had a tendency to cause substantial harm, Palmer J held that due to the common law presumption of damage, the defendant bears the onus of proving that the statement caused "less than minor" harm to the plaintiff's reputation, thus rebutting the presumption. ${ }^{126}$

Although Palmer J appeared to consider this a straightforward reading of Thornton, ${ }^{127}$ it is a misinterpretation which should not be endorsed. Thornton treated the substantial harm threshold as part of the defamatory meaning element, an element which must be proved by the claimant. Therefore it is logical that any extension of this element ${ }^{128}$ must be satisfied by the claimant. This is not inconsistent with the presumption of damage; the presumption becomes relevant once it has been proven that the statement has a tendency to cause harm. ${ }^{129}$

123 Parkes and others, above n 29, at [2.4]. Regrettably, the Court in Cammish did not elaborate on this, or specify what factors might be relevant. Gould, above n 41, considered that "support for both" interpretations of Thornton can be found in Cammish.

124 It is unclear what authorities the authors of Gatley on Libel and Slander were drawing on when they included these factors as part of a Thornton analysis: Parkes and others, above n 29. One citation was supplied, but this was for a High Court judgment delivered in 2009 (Haji-Ioannou v Dixon [2009] EWHC 178 (QB)), which is of limited use in expounding the principles of Thornton, a judgment released in 2010.

125 Sellman v Slater, above n 1, at [63].

126 At [3] and [69].

127 At [62].

128 If indeed it is an extension. As noted in Part IV(B), on one view it is simply an articulation of what was already inherent in the defamatory meaning element.

129 This is in accordance with the explanation given in Rogers and others, above n 30, at [4.04], that Thornton retains the presumption but "confine[s] the application of that principle to cases which reached an appropriate level of gravity." This is also the approach taken by the Court of Appeal in Lachaux v Independent Print Ltd (CA), above n 4 , at [70]. 
Additionally, Palmer J replaced the requirement for substantial harm with a requirement for more than minor harm. ${ }^{130}$ No authority was cited for lowering the standard. Palmer J considered that serious harm was too high a bar, noting that defamation which causes less than serious but more than minor harm to reputation could be reflected in a nominal award of damages, combined with a declaration of defamation. ${ }^{131}$ This is in conflict with Jameel which if utilised to its fullest extent, could eliminate claims where only nominal damages are likely to be awarded. ${ }^{132}$

\section{Should Thornton be endorsed in New Zealand?}

The Thornton threshold is a valuable addition to New Zealand's defamation law, and the endorsements of Dobson and Palmer JJ highlight the judicial appetite for it (although unfortunately, the thresholds the judges articulated differed from the original Thornton threshold in crucial ways). Thornton raises little conceptual difficulty and, arguably, is already inherent in the defamatory meaning tests. It goes some way to protecting freedom of expression rights without creating an unreasonable hurdle for claimants. Worthy claimants will not need to provide evidence to satisfy the threshold, the court need only examine whether the words have a tendency to cause substantial harm.

Regrettably, neither of the New Zealand decisions which endorsed the Thornton threshold went on to correctly restate the test. Clarification is required in several respects. It should be confirmed that it is the claimant who bears the burden of proof, and that the inquiry is confined to the meaning of the words only. It must also be conclusively decided what level the threshold is pitched at. This article proposes that a requirement of substantial harm is a sufficient bar to trivial claims and is a straightforward application of Thornton, ${ }^{133}$ whereas a requirement of more than minor harm is unsupported by precedent and, in any case, provides a weaker barrier to trivial claims. It is unclear whether serious harm differs from substantial harm in practical effect, or if the wording change by the United Kingdom Parliament was merely symbolic. ${ }^{134}$ Further development of the case law will improve clarity regarding how grave the meaning of a statement need be before the substantial harm standard is satisfied.

\section{TWIN TRACK IS PREFERABLE TO FUSION}

A possible but inadvisable method of implementing Jameel and Thornton in New Zealand would be fusion of the two tracks. There are multiple ways that fusion could occur, with the obvious approach being legislation based upon the existing blueprint for fusion: s 1 of the Defamation Act

130 Sellman v Slater, above n 1, at [68.

131 At [68].

132 Opai v Culpan (No 2), above n 1, at [75].

133 Tugendhat J considered at [95] of Thornton, above n 14, that "substantial" was "the lowest threshold that might be envisaged" from the case law.

134 Parkes and others, above n 65, at [2.7]; and Collins, above n 28, at [7.18]. 
2013. Were New Zealand to take the approach envisioned by s 1, harm would become an additional ingredient of the tort to be proved by the claimant on the balance of probabilities. This would require the claimant to show, by reference to external evidence such as the number of publishees, that harm occurred (or is likely to). The following discussion canvasses the benefits of fusion but concludes that it is not desirable. This article does not assert that fusion would, by necessity, produce disastrous results, but argues that it is an unnecessary complication of two distinct principles.

The first advantage of fusion is that it goes further in tipping the scales for defendants. Placing an affirmative burden on the claimant to prove harm up front provides a stronger barrier to trivial claims. Depending on how excessively plaintiff-friendly one perceives the tort, this could be considered a reasonable correction to the balance. The problem is that it tips the scales too far. Requiring claimants to supply evidence of harmful consequences eradicates the presumption of harm, which is a feature of defamation law precisely because "[o]btaining evidence of serious reputational harm is notoriously difficult." ${ }^{135}$ As noted in Jameel, the presumption has strong pragmatic utility, and its removal opens the door to both parties marshalling witnesses to attest that they did or did not consider that the article damaged the claimant's reputation. ${ }^{136}$ This is an unreasonable hurdle to expect claimants to jump.

Of course, both the High Court and Court of Appeal Lachaux judgments acknowledged that harm could be inferred where the meaning of the allegation was sufficiently serious. ${ }^{137}$ In every defamation case, then, the judge would need to decide whether or not to draw an inference, potentially leading to inconsistent outcomes. ${ }^{138}$ To make it even simpler to satisfy this element, the legislation could incorporate Thornton-style language, instructing the courts to draw an inference if the publication has a "tendency" to cause harm. This route would go some way to circumvent what the Court of Appeal in Lachaux labelled the "conceptual impenetrability" of s $1 .{ }^{139}$ It would lessen the burden on claimants and allow inferences to be drawn as a matter of course, based on the meaning of the statement alone.

This form of fused approach would not prevent defendants from adducing evidence to count against drawing an inference, as they would in a Jameel application. Accordingly, the approach is largely unobjectionable, but it does not offer anything beyond what is achieved through keeping the principles separate. In fact, it is essentially the method articulated by the Court of Appeal in Lachaux,

135 Wilson and Double, above n 57.

136 Jameel, above n 1, at [31]. Alternative ways for a claimant to prove harm include commissioning an opinion poll survey, or producing a selection of comments from the blogosphere: Cooke v MGN Ltd, above n 55, at [43].

137 Lachaux v Independent Print Ltd (HC), above n 39, at [57]; and Lachaux v Independent Print Ltd (CA), above $\mathrm{n} 4$, at $[70]$.

138 Parkes and others, above n 65, at v.

139 Lachaux v Independent Print Ltd (CA), above n 4, at [62]. 
which the Court did not characterise as a fused approach at all. ${ }^{140}$ If this approach were adopted it would be crucial to ensure that defendants are able to make arguments against drawing such an inference in a strike out application or other preliminary stage, so as not to weaken a key strength of Jameel: the ability to extinguish trivial claims early.

Another benefit of fusion is its potential to simplify matters for the parties and the courts because it necessitates only one inquiry: in all the circumstances, has the claimant suffered harm? This would end confusion caused by the overlap between Jameel and Thornton, which both hinge on a requirement of minimal harm. However, fusion creates problems of its own. In particular, a flow on effect of eradicating the presumption that damage occurs at the moment of publication is the timing issue it creates. Because the s 1 approach requires an examination of whether, in the circumstances, serious harm has actually occurred, there is the potential for claims to drift "in and out of actionability", depending on what consequences have occurred. ${ }^{141}$ To use the facts of Jameel as an example, suppose that a month after the hyperlink was posted, some readers tracked Jameel down and threw bricks through his windows. At that point, he has suffered harm - but is it too late? To avoid uncertainty, there must be a point in time at which the tort crystallises and no subsequent events can be considered. The judges in Cooke and Lachaux considered this question and reached different answers: Bean J held that the tort crystallised on the date proceedings were brought, ${ }^{142}$ while Davis LJ considered that it was the moment of publication. ${ }^{143}$ Not only is this inconsistency troublesome, but the decision to freeze time at the moment of publication for $\mathrm{s} 1$ purposes also undermines the desire to encourage swift and prominent apologies. ${ }^{144}$

Retaining the presumption of damage avoids the need to address this question: it is conceptually uncomplicated to confine the Thornton analysis to the meaning of the words alone and, as such, the tort crystallises once those words are published. This also ensures predictability because if the substantial harm analysis is confined to the meaning of the words only, defendants can make an objective analysis pre-publication as to whether the words are defamatory. ${ }^{145}$ Any events which took

140 As discussed in Part IV(D), the Court interpreted s 1 as a codification of Thornton.

141 Lachaux $v$ Independent Print Ltd (CA), above n 4, at [60]. It should be noted that the Jameel principle does permit this, in that a statement could transition from defamatory to non-defamatory if the harm was largely or entirely mitigated post-publication, for example through a successful lawsuit over the same subject matter, or a public apology: Hamaizia v Commissioner of Police for the Metropolis [2013] EWHC 848 (QB). Crucially though, Jameel does not enable a statement to transition from non-defamatory to defamatory.

142 Cooke v MGN Ltd, above n 55, at [32].

143 Lachaux $v$ Independent Print Ltd (CA), above n 4, at [67]. A third possibility, the date at which the issue is determined, was flagged by Warby $\mathrm{J}$ in Lachaux v Independent Print Ltd (HC), above n 39, at [67].

144 Joint Committee on the Draft Defamation Bill, above n 45, at [10]. This matter was decisive in Cooke v MGN $L t d$, above $\mathrm{n} 55$, in which the claim was struck out on s 1 grounds due to a prominent apology.

145 Callus, above n 57. 
place post-publication (for example, an apology) could only be relevant to a Jameel application. Overall, while fusion may initially seem to be the less complicated approach, the advantages of merging the principles are not persuasive.

\section{A Is Legislation Needed?}

Parliamentary intervention through amendment to the Defamation Act 1992 would perhaps be the most effective way to solidify these doctrines. Legislating could also have symbolic effect, in that the presence of a legislative bar could be sufficient in itself to deter unworthy claims. ${ }^{146}$ However, the United Kingdom experience with s 1 suggests that legislative change in this area should be done with caution, and would arguably be more appropriate in the context of a wide reform of the Defamation Act $-\mathrm{a}$ discussion which is beyond the scope of this article. ${ }^{147}$ On balance, legislative change is not necessary at this stage. The courts have shown readiness to adopt both doctrines, which are a consistent and natural development of the common law. All that is required is clarification. Additionally, allowing this area to develop through common law retains flexibility.

\section{CONCLUSION}

While there is support for both the Thornton threshold and Jameel principle in New Zealand law, both will benefit from confirmation and clarification at appellate level. Clarification will reap positive outcomes for claimants, defendants and the courts. In order to avoid the difficulties which have plagued the United Kingdom, the two doctrines should not be fused.

146 Lachaux v Independent Print Ltd (CA), above n 4, at [78].

147 See Ali Romanos "Opinion: England's new defamation legislation sets benchmark" NZ Lawyer Magazine (online ed, United Kingdom, 5 Februrary 2014) in which Romanos advocates for wide legislative reform but concludes that as this is unlikely to happen in the near future: "the courts should not be inhibited to develop New Zealand's defamation law when the opportunity arises." 